\begin{tabular}{l}
\hline Jurnal Scripta Teologi dan Pelayanan Kontekstual \\
ISSN \\
ISSN \\
Http://ejournal.stte.ac.id \\
Vol.1, No.1, pp. 164-180, 2019
\end{tabular}

\title{
Seks Menurut Alkitab Sebagai Kontribusi Bagi Pengajaran Gereja Masa Kini
}

\author{
Junius Halawa \\ ${ }^{1}$ Sinode GPIN
}

INFO ARTIKEL
Sejarah Artikel:
Diterima : 10 Nov 2019
Direvisi : 15 Nov 2019
Disetujui: 20 Nov 2019
Dipublikasi: 28 Nov
2019

Kata Kunci:

Seks,

Alkitab,Kontribusi, Pengajaran.

Keywords:

keyword one, keyword two, keyword three.

\begin{abstract}
ABSTRAK
Seks menurut Alkitab sebagai kontribusi bagi pengajaran gereja masa kini. Tujuan tulisan ini untuk menggali dan menjelaskan konsep seks di dalam Alkitab. Alkitab adalah firman Allah tertulis sebagai landasan iman dan sumber pengajaran yang sehat, misalnya pendidikan seks kepada jemaat. Jauh sebelum manusia diciptakan Allah telah merancang seks bagi kehidupan manusia. Sehingga seks harus dipahami sebagai karunia Allah yang baik, mulia dan nikmat. Namun pada faktanya sebagian orang mengangap seks sebagai sesuatu yang kotor atau hanya pemuas hawa nafsu manusia. Konsekwensiya ialah banyak orang melakukan tindakan seks yang salah diantaranya: perzinahan, onani atau mastrubasi, homoseksual, lesbian dan pedofilia. Berdasarkan hasil penggalian Alkitab, maka seks menggunakan istilah: "satu daging" dan "bersetubuh". Lebih dalam Alkitab menyatakan bahwa seks merupakan inisiatif Allah sendiri kepada laki-laki dan perempuan, sehingga seks baik adanya. Seks hanya diizinkan Allah kepada seorang laki-laki dan seorang perempuan yang telah masuk dalam pernikahan yang diberkati Tuhan. Pada hakekatnya seks memiliki empat dimensi, yakni: Dimensi rekreasi, dimensi prokreasi, dimensi relasi dan dimensi refleksi. Jika diamati secara baik antara konsep seks yang disaksikan oleh Alkitab dengan perilaku manusia diera ini, maka telah telah banyak terjadi penyimpangan. Oleh karena itu, fenomena ini merupakan bagian dari tanggungjawab gereja dan hamba Tuhan untuk melakukan langkah-langkah pencegahan dan penangan dosa seksual diantaranya: Memberikan pengajaran seks yang Alkitabiah, membuat program yang kreatif dan inofatif dan melaksanakan pelayanan pastoral konseling. Kata kunci: seks atau seksual.
\end{abstract}

\footnotetext{
ABSTRACT

Sex according to the Bible as a contribution to the teaching of the church today. The purpose of this paper is to explore and explain the concept of sex in the Bible. The Bible is the written word of God as a foundation of faith and a source of healthy teaching, for example sex education to the congregation. Long before humans were created God had designed sex for human life. So sex must be understood as a gift from God that is good, noble and delicious. But in fact some people regard sex as something dirty or just satisfying human desires. The consequence is that many people commit wrong sexual acts including:
} 
adultery, masturbation or masturbation, homosexuals, lesbians and pedophilia. Based on the results of the excavation of the Bible, sex uses the terms: "one flesh" and "intercourse". More in the Bible states that sex is God's own initiative to men and women, so sex is good. Sex is only permitted by God to a man and woman who have entered into a blessed marriage by God. Basically sex has four dimensions, namely: the recreation dimension, the dimension of procreation, the dimension of relations and the dimension of reflection. If observed properly between the concept of sex witnessed by the Bible with human behavior in this era, then there have been many deviations. Therefore, this phenomenon is part of the responsibility of the church and servants of God to take steps to prevent and deal with sexual sins including: Providing biblical sex teaching, making creative and innovative programs and carrying out pastoral counseling services. Keywords: sex or sexual.

\section{Pendahuluan}

Pada mulanya Allah menciptakan laki-laki dan perempuan. Tuhan memberikan mereka gender (orientasi seksual) sebagai laki-laki dan perempaun. Hal yang sama dituliskan Hanry C. Thiessen, bahwa sebelum Allah menghembuskan nafas-Nya ke dalam mereka, pastilah mereka sudah dalam berupa makhluk jantan dan betina, tetapi Alkitab menyatakan bahwa Allah yang menciptakan mereka sebagai laki-laki dan perempuan (Kej. 1:17, 2:7, Mat. 19:4). Maka Allah dalam kedaulatan-Nya la menjadikan Adam dan Hawa sebagai pasangan yang masing-masing diberikan alat reproduksi dan orientasi seksual yang berbeda.

Selanjutnya Alkitab mengemukakan bahwa seks adalah baik dan kudus adanya. Kejadian 2:25, "Mereka keduanya telanjang, manusia dan istrinya itu, tetapi mereka tidak merasa malu". Sebelum manusia jatuh di dalam dosa mereka tidak menutupi auratnya sebagai tanda bahwa mereka tidak merasa malu, takut atau cemas. Adam dan Hawa sebagai suami istri hidup dalam hubungan seksual yang indah, menyenangkan, sentosa dan bahagia. Kemudian Tuhan menciptakan seks bagi manusia sebelum mereka jatuh dalam dosa, sehingga seks adalah kudus dihadapan Tuhan. Jauh sebelumnya Allah telah merancang adanya seks atau hubungan seksual bagi manusia. Seks harus dipahami sebagai ciptaan Allah yang baik, kudus, indah dan menyenangkan. Seks adalah anugrah Allah bagi manusia. Oleh karena itu, hubungan seksual antara laki-laki dan perempuan harus dilakukan dalam kekudusan Tuhan. Oleh karena itu, perilaku seks seperti seks sebelum menikah, seks sejenis, pedophilia, dan lain sebagainya sangat ditentang oleh Allah.

Pada faktanya seks seringkali disalah artikan atau tidak umum dibicarakan dikalangan masyarakat. Sebagaimana ditegaskan oleh C. L. Ch. Abineno, bahwa masih banyak anggota jemaat yang mempunyai pendapat yang salah tertang hubungan seksual, bahkan ada juga diantara mereka yang mengangap hubungan seksual itu tabu dan kotor. Hal ini salah satu penyebab orang tua dan gereja tidak mengajarkan seks secara baik, sehingga banyak jemaat memiliki konsep dan perilaku seks yang keliru.

Konsep dan perilaku seks yang salah juga disebabkan oleh kemajuan ilmu teknologi (IT) yang begitu pesat. Kemajuan teknologi satu sisi menolong manusia dalam hal bekerja, berusaha, berbisnis, berkomunikasi dan lain sebagainya. Misalnya pada bidang komunikasi, aplikasi media seperti Facebook, WhatsApp (WA), Black 
Berry Messenger (BBM), Line, Twitter, mempermudah interaksi manusia antara satu dengan yang lain. Namun disisi lain kemajuan teknologi telah menjadi tantangan bagi manusia. Tantangan yang dimaksud ialah merusak keadaban manusia, terjadinya degradasi moral, merubah tatanan sosial dan juga dapat merusak spiritual seseorang. Satu contoh aplikasi geogle memudahkan seseorang untuk mengakses berbagai macam informasi baik yang positif maupun negatif. Hal negatif seperti membuka situs yang berbau pornografi akan membangkitkan gairah seksual seseorang dan mengarah pada perilaku negatif seperti chyber sex, free sex, onani, mastrubasi dan seks sebelum menikah. Pemahaman mengenai seks yang terbatas yang berakibat pada perilaku seks yang salah merupakan tantangan serius bagi gereja. Oleh karenanya, gereja tidak boleh berdiam diri. Namun gereja harus proaktif melakukan upaya pencegahan agar generasi masa depan hidup dalam kekudusan seksual. Salah satu upaya yang bisa dilakukan ialah gereja atau para hamba Tuhan memberikan pengajaran mengenai seks yang alkitabiah kepada semua anggota gereja.

\section{Metode Penelitian}

Dalam Penulisan ini metode yang dipakai dalam penelitian adalah Metode Penelitian Komparatif - Penelitian komparatif merupakan jenis penelitian deskriptif yang berusaha mencari jawaban secara mendasar mengenai sebab-akibat, dengan menganalisis faktor-faktor penyebab terjadinya maupun munculnya suatu fenomena atau kejadian tertentu. Penelitian komparatif merupakan penelitian yang sifatnya membandingkan, yang dilakukan untuk membandingkan persamaan dan perbedaan dua atau lebih sifat-sifat dan fakta-fakta objek yang diteliti berdasarkan suatu kerangka pemikiran tertentu. Penelitian komparatif biasanya digunakan untuk membandingkan antara dua kelompok atau lebih dalam suatu variabel tertentu.

\section{Hasil Dan Pembahasan \\ Pengertian Seks}

Istilah "seks" berasal dari bahasa Latin "sexus" kemudian diturunkan menjadi bahasa Perancis Kuno "sexe". Istilah ini diterjemahkan dalam bahasa Inggris sebagai kata benda "noun", kata sifat "adjective", maupun kata kerja transitif "verb of transitive". Kamus Besar Bahasa Indonesia (SBBI) kata "seks" diartikan: jenis kelamin, hal yang berhubungan dengan alat kelamin seperti sanggama, dan berahi. Seks adalah perbedaan badani atau biologis perempuan dan laki-laki yang sering disebut jenis kelamin.

\section{Pengertian Seksualitas}

Istilah "Seksualitas" lebih luas artinya dari pada kata seks saja. Seksualitas mengrangkap hubungan batin antara manusia, terutama antara dua orang yang jenis kelaminnya berbeda. Seksualitas tidak terbatas pada nafsu birahi, akan tetapi juga merangkap "cinta dan sayang". Dengan demikian, Seks adalah hubungan badani antara seorang laki-laki dan perempuan sebagai wujud ungkapan kasih dan sayang diantara keduanya.

\section{Perilaku Seks yang Salah}


Seks yang dianugrahkan Tuhan kepada manusia pada hakikatnya baik dan nikmat. Seks diberikan oleh dengan maksud dan tujuan yang mulia. Namun kejatuhan manusia di dalam dosa sangat berpengaruh terhadap semua aspek kehidupannya termasuk dalam hal tindakan seksual. Seks dipahami sebagai pemenuhan hawa nafsu semata tanpa menghiraukan kekudusan seksual di hadapan Allah. Beberapa perilaku seksual yang salah yang kerap dilakukan manusia, sebagai berikut:

\section{Perzinahan}

Dalam Perjanjian Lama, perzinahan dipandang sebagai suatu tindakan di mana terjadi hubungan badan antara laki-laki dan perempuan yang tidak terikat oleh sebuah ikatan pernikahan secara hukum maupun secara adat. Dalam hal ini suatu tindakan dapat dikategorikan sebagai perzinahan apabila ada kontak tubuh yang terjadi antara laki-laki dan perempuan tersebut dalam dorongan seksual, tanpa direstui oleh masyarakat baik secara hukum maupun adat serta adanya pihak ketiga dalam pernikahan. Jadi perzinaan terjadi apabila seseorang melakukan persetubuhan (carnal intercourse) dengan orang lain yang telah menikah (Ulangan 22:22; Imamat 20:10). Dalam Perjanjian Lama dosa jenis ini sangat dikutuk sehingga Allah mencantumkan hukum larangan berzinah ini dalam Dasa Titah.

Dalam Perjanjian Baru, Tuhan Yesus membuat rumusan tentang perzinahan yang berbeda dengan konsep Perjanjian Lama. Dalam Matius 5:27-28 Tuhan Yesus berkata: Kamu telah mendengar firman: Jangan berzinah. Tetapi Aku berkata kepadamu: "Setiap orang yang memandang perempuan serta menginginkannya, sudah berzinah dengan dia di dalam hatinya". Tuhan Yesus mengisyaratkan bahwa suatu tindakan dapat dikategorikan perzinaan tidak harus atau tidak perlu lebih dulu adanya unsur kontak tubuh. Bila seseorang memandang lawan jenisnya dan tergerak nafsu birahinya dan menikmati dalam pikiran, maka tindakan ini sudah dapat dikategorikan sebagai perbuatan zinah. Dalam hal ini Tuhan Yesus sangat memperhatikan motivasi dasar yang mendorong seseorang melakukan suatu tindakan. Dosa tidak ditentukan pada apa yang kelihatan saja, tetapi juga apa yang tidak kelihatan yaitu motivasi hati. Inilah yang sering juga disebut zinah dalam hati. Alkitab mendefenisikan perzinahan merupakan aktifitas seksual yang dilakuan oleh seorang laki-laki atau seorang perempuan baik berhubungan badan secara langsung maupun pemuasan seks di dalam perasaan dan pikiran terhadap lawan jenis yang bukan pasangan suami-istri. Perzinahan salah satu dosa sangat dilarang dan dibenci oleh Allah (Keluaran 20:14; Ulangan 5:18; Matius 5:27; 1 Tesalonika 4:3). Dalam sejarah bangsa Israel setiap orang yang melakukan perzinahan akan dihukum mati (Imamat 18:20, 22, 29). Dengan demikian, perzinahan ialah perbutan yang ditentang oleh Allah sehingga siapa saja yang melakukannya akan menerima hukuman dari Tuhan.

\section{Onani Atau Mastrubasi}

Kata "onani" dalam bahasa Ibrani diterjemahkan darin) artinya: "kuat". Onan adalah adalah nama putra kedua Yehuda dan istrinya Batsyua atau anak perempuan dari Syua seorang Kanaan. Ketika abangnya yang bernama Er mati, Onan disuruh oleh Yehuda ayahnya untuk menikahi Tamar janda abangnya. Kata Yehuda: "Hampirilah isteri kakakmu itu, kawinlah dengan dia sebagai ganti kakakmu dan bangkitkanlah keturunan bagi kakakmu”. Tetapi Onan tahu bahwa bukan ia yang empunya keturunannya nanti, sebab itu setiap kali ia menghampiri isteri kakaknya itu, 
ia membiarkan maninya terbuang supaya ia jangan memberi keturunan kepada kakaknya. Tetapi yang dilakukannya itu adalah jahat di mata Tuhan, maka Tuhan membunuh dia (Kejadian 38:1-30).

Berangkat dari kisah Onan muncul istilah kata onani dengan pengertian seorang laki-laki yang mengeluarkan air maninya dengan merasang dirinya sendiri. Onani memiliki motifasi untuk mendapatkan kenikmatan biologis tanpa berhubungan dengan lawan jenis. Sedangkan mastrubasi adalah proses memperoleh kepuasan seks tanpa berhubungan kelamin. Menurut S. Kruyt, mastrubasi adalah alat kelamin sendiri digosok-gosok dengan tangan, dengan maksud merangsang-rasangnya sampai menimbulkan rasa orgasme. Jika dilihat dari defenisi kata onani atau mastrubasi keduanya memiliki aktifitas yang sama yaitu seorang laki-laki atau perempuan yang melakukan aktifitas seksual oleh dirinya sendiri sampai mengalami ejakulasi atau orgasme. Ada beberapa faktor seorang laki-laki melakukan onani atau mastrubasi diantaranya memandang lawan jenis dengan nafsu birahi, pornografi dan merasa rendah diri. Misalnya melihat pornografi akan berimajinasi tentang seks, kemudian menimbulkan rangsangan seksual dan salah satu cara untuk memperoleh kepuasan dengan melakukan onani.

Dalam perspektif iman Kristen onani atau mastrubasi dapat dikategorikan sebagai dosa percabulan dikarenakan bertujuan untuk pemuasan hasrat seksual yang tidak normal. Seseorang yang melakukan onani atau mastrubasi membiarkan pikiran, perasaan dan anggota-anggota tubuhnya berbuat kenajisan di hadapan Tuhan. Tulisan Rasul Paulus di dalam Kolose 3:5 "Karena itu matikanlah dalam dirimu segala sesuatu yang duniawi, yaitu percabulan, kenajisan, hawa nafsu, nafsu jahat dan juga keserakahan, yang sama dengan penyembahan berhala".

\section{Homoseksual}

Dalam Kamus Besar Bahasa Indonesia kata "homoseks" berarti: hubungan seks dengan pasangan yang sejenis. Sedangkan kata "homoseksual" berarti: keadaan tertarik terhadap orang dari jenis kelamin yang sama. Homoseksual menuai prokontra dikalangan masyarakat. Sebagian orang setuju dengan homoseksual. Beberapa alasan yang dilontarkan ialah alasan genetik (orientasi seksual sejak lahir) dan alasan hak asasi manusia. Argumen yang kelihatannya masuk di akal, gereja ikut terjebak di dalamnya. Realitas menunjukkan bahwa ada gereja yang melaksanakan pemberkatan nikah sejenis (laki-laki dengan laki-laki) dimana sudah bisa dipastikan bahwa pasangan tersebut yang dipraktekan ialah hubungan homoseksual.

Fakta homoseksual juga dikisahkan dalam Alkitab yakni peristiwa Sodom dan Gomora. Kejadian 19:5-6 "Tetapi sebelum mereka tidur, orang-orang lelaki dari kota Sodom itu, dari yang muda sampai yang tua, bahkan seluruh kota, tidak ada yang terkecuali, datang mengepung rumah itu. Mereka berseru kepada Lot: "Di manakah orang-orang yang datang kepadamu malam ini? Bawalah mereka keluar kepada kami, supaya kami pakai mereka". Dalam teks Ibraninya kata "pakai" menggunakan kata "yada" yang berarti kesatuan oleh sebab hubungan seksual. Nafsu birahi laki-laki kota Sodom ingin menyetubuhi malaikat Tuhan yang menampakkan diri dalam wujud lakilaki. Peristiwa ini menyaksikan bahwa permasalahan homoseksual sudah ada sejak zaman Perjanian Lama.

Homoseksual adalah perbutan yang tidak normal serta dosa yang sangat dibenci oleh Tuhan. Alkitab menuliskan bahwa tidur dengan laki-laki secara orang bersetubuh 
dengan perempuan merupakan perbutan kekejian (Imamat 18:22). Selanjutnya firman Tuhan dalam Imamat 20:13: "Bila seorang laki-laki tidur dengan laki-laki secara orang bersetubuh dengan perempuan, jadi keduanya melakukan suatu kekejian, pastilah mereka dihukum mati dan darah mereka tertimpa kepada mereka sendiri". Homoseksual adalah perbuatan yang sangat ditentang oleh Allah. Oleh karenanya barang siapa yang melakukannya akan menerima hukuman dari Tuhan. Ayat-ayat kitab suci ini menegaskan bahwa gereja tidak boleh memberikan ruang bagi pelaku homoseksual (pernikahan sejenis), namun gereja harus menjadi gardan terdepan untuk menolak dan mengatasinya.

\section{Lesbian}

Lesbian adalah perempuan yang memiliki hasrat seksual dan emosi kepada perempuan lain. Secara sederhana lesbian diartikan dengan seks sejenis yang artinya seseorang yang memiliki kecenderungan atau ketertarikan (orientasi) seksual dengan sesama jenisnya. Salah satu ciri dari lebian adalah menutup diri terhadap dunia luar. Sifat tertutup lesbian terletak pada norma budaya bahwa perempuan lebih mengutamakan perasaan. Rasa malu dan rendah diri menimbulkan tekanan psikolgi sehingga memilih untuk mengurung diri. Sama halnya dengan homoseksual dipahami bahwa lesbian memiliki faktor biologis (genetik) yakni bawaan sejak lahir. Selanjutnya seseorang dapat menjadi lebian karena pengaruh lingkungan sosial. Lesbian sejak jaman dulu hingga saat ini masih merupakan suatu fenomena yang penuh dengan kontroversi. Sepanjang sejarah perilaku ini dikaitkan dengan konotasi negatif, yaitu perilaku amoral sehingga sering terjadi tindakan diskriminatif di lingkungan masyarakat.

Jika dikaji dari sudut pandang iman kekristenan, maka sejak semula Tuhan menciptakan manusia sempurna segambar dan serupa dengan Allah (Imago Dei) yaitu laki-laki dan perempuan. Inilah kodrat sesungguhnya dari identitas gender manusia atau yang sering disebut orientasi seksual. Seperti tertulis dalam Kutab Suci: "Maka Allah menciptakan manusia itu menurut gambar-Nya, menurut gambar Allah diciptakanNya dia; laki-laki dan perempuan diciptakan-Nya mereka" (Kejadian 1:27). Tuhan juga memberkati hubungan laki-laki dengan perempuan dalam ikatan yang kudus dengan maksud untuk berkembang biak dan memenuhi bumi. Allah memberkati mereka, lalu Allah berfirman kepada mereka: "Beranak cuculah dan bertambah banyak; penuhilah bumi dan taklukkanlah itu, berkuasalah atas ikan-ikan di laut dan burung-burung di udara dan atas segala binatang yang merayap di bumi" (Kejadian 1:28). Laki-laki diciptakan untuk memiliki relasi seksual dengan perempuan (istri) dan sebaliknya perempuan dengan laki-laki (suami) untuk menjadi satu daging. Dan ini hanya terjadi dalam ikatan pernikahan monogami (Kejadian 2:23-24).

Ketika manusia jatuh dalam dosa, maka manusia mengalami kerusakan dalam nilai-nilai moral yang dipegangnya. Manusia menentang Allah dan berusaha memuaskan keinginannya dengan cara-cara yang cemar termasuk dalam hal seksualnya. "Karena itu Allah menyerahkan mereka kepada keinginan hati mereka akan kecemaran, sehingga mereka saling mencemarkan tubuh mereka" (Rom. 1:24). Manusia telah mengganti persetubuhan yang wajar dengan tidak wajar (homoseks, lesbian, pedofilia, inses, necrofillia, dan lain sebagainya) seperti firman Allah tertulis: "Karena itu Allah menyerahkan mereka kepada hawa nafsu yang memalukan, sebab isteri-isteri mereka menggantikan persetubuhan yang wajar dengan yang tak wajar" (Rom. 1:26). 
Sifat dosa yang diwariskan turun temurun mengakibatkan dampak disorientasi seksual manusia. Jadi seorang yang memiliki orientasi lesbian bukan rencana Allah atau tidak dikehendaki oleh Tuhan.

\section{Pedofilia}

Kata pedofilia berasal dari bahasa Yunani $\pi a ı \delta o \varphi \iota \lambda \iota a$ (paidophilia) dibagi dalam dua kata yaitu: тaıৎ (pais) artinya: "anak-anak" dan $\varphi \iota \lambda \iota a$ (philia) "cinta yang bersahabat" atau "persahabatan". Berdasarkan arti akar kata tersebut pedofilia adalah seseorang memiliki hubungan yang kuat dan berulang terhadap dorongan seksual dan fantasi tentang anak-anak prapuber dan di mana perasaan mereka memiliki salah satu peran atau yang menyebabkan penderitaan atau kesulitan interpersonal. Perilaku pedofilia merupakan gangguan seksual yang berupa nafsu seksual terhadap remaja atau anak-anak di bawah umur. Ciri pedofil berdasarkan sifat, karakter dan kebiasaannya yaitu cenderung memiliki sifat obsesif yang berlebihan, memiliki agresif yang tinggi, introvert (suka menyendiri), pintar merayu dan layaknya predator yang memangsa siapapun anak yang ada di depannya.

\section{Faktor Perilaku Seks Yang Salah}

Sebelum melakukan pembahasan lebih jauh, maka penting untuk mengetahui terlebih dahulu apa saja yang menyebabkan seseorang melakukan perbuatan seks yang salah, yakni:

\section{Biologis}

Masa remaja (Adolescence) sebagai periode transisi perkembangan antara masa kanak-kanak dengan masa dewasa, yang melibatkan perubahan-perubahan biologis, kognitif, dan sosio-emosional. Aspek perubahan fisik yang dialami remaja berhubungan dengan produksi hormon seksual dalam tubuh yang mengakibatkan timbulnya dorongan emosi dan seksual. Hal ini menjadi titik rawan karena remaja mempunyai sifat selalu ingin tahu dan mempunyai kecenderungan mencoba sesuatu yang baru. Masa pubertas bagi remaja merupakan masa krisis untuk mencari jati diri yang sesunggunya. Berusaha mengaktualisasikan diri pada lingkungannya termasuk gairah seksual terhadap lawan jenisnya, sehingga perilaku seks yang salah kebanyakan terjadi di usia remaja.

\section{Pacaran}

Pacaran merupakan proses perkenalan antara dua insan manusia yang biasanya berada dalam rangkaian tahap pencarian kecocokan menuju kehidupan berkeluarga yang dikenal dengan pernikahan. Berpacaran adalah interaksi heteroseksual yang didasari oleh rasa cinta, kasih dan sayang untuk menjalin suatu hubungan yang lebih dekat. Pada esensinya pacara ialah untuk saling mengenal lebih jauh menuju pernikahan atau untuk mencari pasangan hidup. Pacaran sering disalah artikan oleh para generasi muda sehingga timbul perbutan yang menyimpang. Bagi yang berpacaran sering berasumsi bahwa cinta sama dengan seks. Suatu pengertian yang menyesatkan dan menjerumuskan. Tidaklah heran jika masa pacaran sudah bersikap negatif seperti ciuman, pelukan, meraba, dan petting yang mengorong melakukan tindakan seks sebelum waktunya. Oleh karena itu, dapat dipastikan masa pacaran salah satu penyebab utama terjadinya hubungan seks terlarang. 


\section{Kurangnya Pendidikan Seks}

Bagi sebagian orang seks memang masih dianggap tabu dan konsumsi orang dewasa. Sehingga berbicara mengenai seks harus secara tersembunyi. Membicarakan seks kepada anak-anak merupakan tugas yang cukup berat. tidak banyak orang tua yang merasa nyaman dalam mengajarkannya. Sepertinya seksualitas merupakan topik memalukan yang sulit dibicarakan dengan baik kepada anak-anak. Semestinya sedini mungkin pendidikan seks harus disampaikan khususnya pada usia remaja. Pada usia ini seorang remaja mengalami perubahan organ-organ seks, baik primer maupun sekunder. Masa ini dikenal sebagai masa pubertas. Masa perubahan fisik pada remaja laki-laki atau perempuan seringkali diabaikan oleh orang tua, guru, bahkan para hamba Tuhan sehingga para remaja perempuan tindak mendapat pengetahuan seks yang baik. Akibat dari kurangnya pengetahuan tentang seks, seringkali perilaku seks menjadi salah arah. Oleh sebab itu, kurangnya pendidikan seks menyebabkan seseorang memiliki konsep seks yang keliru dan berakibat pada tindakan seks yang salah.

\section{Orang Tua}

Penyebab lain dari perilaku seks sebelum menikah ialah latar belakang keluarga. Orang tua merupakan figur utama yang harus diteladani oleh setiap anak. Segala segi perilaku orang tua mulai dari perkataan, kebiasaan, perbuatan akan diamati dan ditiru oleh anak. Orang tua yang relasinya tidak harmonis berdampak pada kurangnya perhatian orang tua kepada anak. Salah satu contoh anak dari korban broken home tidak mendapat perhatian yang seimbang dari kedua orang tuanya. Keadaan ini mempengaruhi prilaku negatif anak. Kemudian pendidikan yang salah dalam keluarga seperti terlalu memanjakan anak, tidak memberikan pendidikan seks sedini mungkin, penolakan terhadap eksistensi anak bisa menjadi penyebab perilaku seks sebelum menikah.

\section{Kemajuan Teknologi}

Dampak keterbukaan informasi dalam era globalisasi baik melalui media cetak maupun elektronik yang semakin canggih telah menyebabkan pergeseran nilai-nilai budaya, moral dan spiritual. Kemajuan teknologi terutama media elektronik dan media massa menyajikan beragam informasi tentang hal-hal yang bisa memengaruhi perilaku negatif bagi masyarakat secara khusus generasi muda. Alat teknologi seperti internet, handphon dan aplikasi media lainnya menjadi sarana untuk bisa mengakses hal-hal yang berkaitan dengan seksual sulit untuk dibendung, pada akhirnya telah menimbulkan hal yang negatif seperti mengakses hal-hal yang berbau pornografi. Tidak bisa dibantah bahwa teknologi telah memberikan pengaruh signifikan bagi semua aspek kehidupan manusia mulai dari cara berpikir, moral, etika, tingkah laku, karakter, termasuk perilaku seksual. Aplikasi media sosial menawarkan berbagai macam situs-situs yang muatannya pornografi diantaranya aplikasi You Tobe, Facebook, WhatsApp, Instagram dan lain sebagainya. Situs-situs yang bermuatan pornografi sangat mudah diakses dan ditonton oleh semua orang. Bermula dari apa yang dibaca atau dilihat menimbulkan rangsangan seksual yang akan merahkan pada pemenuhan nafsu seksual. Akibatnya ialah melakukan tindakan seks yang salah seperti 
pelecehan seksual, pemerkosaan, perselingkuhan, onani, mastrubasi, seks bebas dan lain-lain.

\section{Dampak Perilaku Seks Yang Salah}

Perilaku seks yang salah memiliki dampak yang sangat serius bagi siapa saja yang melakukannya, diantaranya sebagai berikut:

\section{Dampak Spiritual}

Secara universal manusia hidup dalam gelimang dosa (Roma 3:23). Alkitab mengemukakan bahwa semua tindakan seks yang dilakukan di luar pernikahan yang saha adalah dosa perzinahan atau percabulan (Keluaran 2:14; Matius 5:28). Semua yang berbuat dosa tidak kuasa untuk melepaskan diri dari dosa, karena upah dosa adalah maut ( $\mathrm{Rm} \mathrm{6:23).} \mathrm{Upah} \mathrm{dosa} \mathrm{adalah} \mathrm{maut} \mathrm{mengandung} \mathrm{makna} \mathrm{seseorang} \mathrm{tersebut}$ kehilangan kebahagiaan abadi di Surga. Dosa telah berkuasa untuk menghukum dan membinasakannya. Perbuatan seks sebelum menikah merupakan kejatuhan dalam dosa seksual yaitu perzinahan atau percabulan. Maka, ia harus mengalami pemulihan secara total di dalam Yesus Kristus, jika tidak dia berhadapan dengan hukuman maut.

Pada saat manusia pertama jatuh dalam dosa mata mereka menjadi terbuka dan mereka tahu bahwa, mereka telanjang (Kejadian 3:7). Mereka berusaha menyembunyikan rasa malu dengan menutupi auratnya menggunakan daun pohon ara serta melarikan diri dari hadapan Tuhan (Kejadian 3:8). Dosa menyebabkan rasa bersalah, rasa malu serta menyalahkan diri sendiri. Sehingga seseorang yang diketahui berbuat dosa dia berusaha menarik diri dari persekutuan dengan Allah dan sesama. Perzinahan adalah aib yang menyebabkan rasa malu yang besar baik terhadap dirinya sendiri, orang tua dan kerabat. Disebabkan karena rasa malu tersebut seseorang yang jatuh dalam dosa seksual memilih keluar dari persekutuan orang percaya dan mundur dari pelayanan gereja.

\section{Dampak Psikologis}

Seks sebelum menikah dapat menyebabkan stres emosi, ketidakpercayaan, penyesalan dan kekosongan. Hubungan seks sebelum nikah bisa merusak mental terutama pada perempuan. Perempuan lebih peka dengan emosinya, perempuan juga lebih peka terhadap perasaan-perasaan cemasnya. Secara kognitif perempuan memang memiliki keunikan dan berlainan dengan pria, yakni cenderung melihat hidup atau peristiwa yang dialaminya secara detil. Akibatnya perasaannya tertekan, sulit berkosentrasi dan frustasi.

Selanjutnya dampak psikologi lainya ialah timbulnya rasa takut. Rasa takut merupakan suatu perasaan yang menyakitkan, seperti kegelisahan, kebingungan, kecemasan, kegalauan, kekuatiran dan sebagainya, yang berhubungan dengan aspek subyektif emosi. Seseorang perempuan yang melakukan hubungan seks sebelum yang salah, ada rasa ketakutan yang sangat besar. Takut karena merasa berdosa, takut ditolak orang tua, takut mendapat hukuman, takut hamil, takut kehilangan masa depan. Terlebih lagi rasa takut jika calon suaminya tidak setia kepadanya atau tidak bertanggung jawab atas perbutannya. Kemudian perilaku seks yang salah bisa saja mengubah cara pandang seseorang tentang seks selamanya. Seks seharusnya sesuatu yang sakral dan menjadi sangat indah jika dilakukan oleh pasangan suami istri, tetapi 
jika dilakukan sebelum menikah, maka bisa jadi seks dipandang sebagai suatu yang kotor, menjijikkan, takut dan terlarang.

\section{Dampak Fisik dan Kesehatan}

Ada beberapa dampak fisik dan kesehatan, yaitu:

\section{Tidak Virgin}

Istilah virgin berasal dari bahasa Latin "virgo" yang berarti: gadis, perawan. Istilah ini juga punya kaitan erat dengan istilah virga yang artinya baru, ranting muda atau cabang yang belum berbentuk. Virgin adalah seorang gadis atau perawan yang belum pernah melakukan hubungan seksual, suci atau bersih dan belum pernah di sentuh ataupun dijamah oleh lawan jenisnya. Pada wanita keperawanan ditandai dengan masih utuhnya selaput dara atau selaput dara belum robek. Keperawanan adalah hal yang paling berharga di dalam diri seorang perempuan. Seorang wanita yang melakukan hubungan seks sebelum menikah dia kehilangan keperawanannya sebelum waktunya. Konsep diri menjadi rusak sehingga memadang dirinya hina, tidak berguna dan rendah diri.

\section{Hamil Di Luar Nikah}

Konsekuensi logis dari hubungan seksual ialah kehamilan. Kehamilan adalah serangkaian proses yang dialami oleh perempuan yang diawali dengan pertemuan antara sel telur dan sel sperma di dalam indung telur (ovarium) wanita, lalu berlanjut ke pembentukan zigot, perlekatan atau menempel di dinding rahim, pembentukan plasenta, dan pertumbuhan serta perkembangan hasil konsepsi sampai cukup waktu. Berdasarkan penelitian dari Australian National University (ANU) dan Pusat Penelitian Kesehatan Universitas Indonesia (UI) tahun 2010-2011 di Jakarta, Tangerang dan Bekasi (Jatabek) dengan jumlah sampel 3006 responden (usia 17-24 tahun), menunjukkan 20.9\% remaja mengalami kehamilan dan kelahiran sebelum menikah. Kemudian 38,7\% remaja mengalami kehamilan sebelum menikah dan kelahiran setelah menikah. Dari data tersebut terdapat proporsi yang relatif tinggi pada remaja yang melakukan pernikahan disebabkan oleh karena kehamilan yang tidak diinginkan.

\section{Aborsi}

Istilah aborsi (bahasa Latin: abortus) adalah berakhirnya kehamilan dengan dikeluarkannya janin (fetus) atau embrio sebelum memiliki kemampuan untuk bertahan hidup di luar rahim, sehingga mengakibatkan kematiannya. Aborsi merupakan tindakan untuk mengakhiri kehamilan dengan pengeluaran hasil konsepsi sebelum janin dapat hidup diluar kandungan. Berdasarkan data dari Komisi Perlindungan Anak Indonesia (KPAI) tahun 2013, diketahui sebanyak 32\% remaja usia 14 hingga 18 tahun di kota besar di Indonesia (Jakarta, Surabaya, dan Bandung) pernah berhubungan seksual pranikah dan membuktikan 62,7\% remaja perempuan kehilangan perawan saat masih duduk di bangku SMP, bahkan 21,2\% diantaranya ekstrim, yakni pernah melakukan aborsi. Tindakan aborsi pilihan yang paling banyak dilakukan oleh para perempuan yang hamil akibat melakukan hubungan seks sebelum menikah. Motif aborsi untuk menyembunyikan rasa malu dan aib akibat perbuatannya. 


\section{Penyakit Menular Seksual (PMS)}

Resiko yang lain dari melakukan hubungan seks sebelum menikah ialah Penyakit Menular Seksual (PMS). Penyakit Menular Seksual dapat berujung pada penyakit reproduktif mengerikan dan berbahaya bagi kesehatan terlebih dapat membahayakan sistem imunitas tubuh seperti menyebabkan gonorhoe (penyakit kencing nanah), sifilis (raja singa), kutil kelamin, keputihan, kanker servic, kanker prostat, herpes genitalis, Aquired Immuno Deficiency Syndrome (AIDS), dan lain sebagainya. Bahkan seseorang yang menderita salah satu PMS tersebut dapat menyebabkan kemandulan (infertil) atau jika seseorang terkena penyakit sifilis dan gonorhoe akut pada pria dapat membuat alat vital (penis) meradang dan penis rusak, impotensi, bahkan penis dapat hilang. Dengan demikian, perilaku seks salah dan menyimpang sangat beresiko pada kesehatan baik laki-laki maupun perempaun.

\section{Dampak Sosial}

Perilaku seks sebelum menikah memiliki dampak sosial. Menurut etika sosial budaya bahwa seks sebelum menikah merupakan perilaku asusila atau amoral yang menyebabkan rekasi negatif dari masyarakat lingkungan. Perbuatan asusila tersebut menjadi bahan membicaraan yang hangat dilingkungan tempat tinggal misalnya tetangga, teman, sahabat, kerabat dan masyarakat lainnya. Hal ini akan menimbulkan rasa malu yang besar bagi pelaku sehingga tidak mau bertemu dan bergaul kepada kepada orang lain biasanya memilih untuk mengurung diri atau menjauh dari komunitas. Dampak sosial lainnya pelaku bisa saja mendapat penghakiman atau kekerasan dari masyarakat lingkungan.

\section{Seks Menurut Alkitab}

Ada beberapa dasar seks menurut Alkitab, yaitu:

\section{Seks Adalah Inisiatif Allah}

Alkitab menyaksikan bahwa Allah yang merancang adanya seks dalam kehidupan manusia. Allah dengan sengaja menciptakan laki-laki dan perempuan dengan orientasi seksnya masing-masing (Kejadian 1:27). Sejak semula telah ditetapkannya ada dua jenis kelamin dan itu sungguh amat baik (Kejadian 1:31). Allah melengkapai manusia dengan organ seks dan dorongan seksual. Senada dengan itu dituliskan oleh John White, bahwa: "Allah juga melengkapi tubuh dengan sistim syaraf yang diprogram sedemikian rupa sehingga setiap orang dapat mengalami kenikmatan yang luar biasa, yaitu kenikmatan yang kelak akan tercipta bila Kristus hadir dalam pernikahan dua orang yang saling mencintai". Jauh sebelum manusia diciptakan Allah telah merancang seks bagi manusia. Pada prinsipnya Allah berkenan dan merestui adanya hubungan seks diantara laki-laki dan perempuan. Allah memiliki tujuan mulia menciptakan seks kepada manusia supaya manusia tertarik terhadap lawan jenis, seks diberikan untuk kelangsungan hidup manusia dan Allah memberikan seks kepada lakilaki dan perempuan sebagai suatu cara untuk menyatakan cinta kasih mereka yang total dan dalam satu terhadap yang lainnya. Oleh sebab itu, seks adalah anugrah Allah yang teramat baik untuk dinikmati oleh pasangan laki-laki dan perempuan yang telah dipersatukan dalam pernikahan kudus. 


\section{Seks Adalah Baik}

Seks sudah ada sebelum manusia jatuh ke dalam dosa. Kejadian 2:25, "Mereka keduanya telanjang, manusia dan istrinya itu, tetapi mereka tidak merasa malu”. Teks ini membenarkan bahwa seks bukan sesuatu yang kotor dan menjijikkan oleh karena manusia itu telanjang tapi mereka tidak merasa malu. Lebih tegas dituliskan oleh Jarot Wijanarko bahwa:

Setelah Tuhan menciptakan manusia, sebagaimana manusia itu ada, termasuk organ dan hormon seksualnya, dorongan seksualnya dan kemampuan untuk berkembangbiak, maka Tuhan berfirman, bahwa semua itu baik. Seks adalah kudus, bahkan itu perintah Tuhan. Seks bukan sesuatu yang masuk ke dalam manusia setelah manusia jatuh dalam dosa, bukan, seks yang ada dalam diri manusia adalah karya Tuhan.

Seks adalah hal yang terindah, mempesona dan menyenangkan bagi setiap orang yang telah berhak menikmatinya. Namun tindakan seks yang dilakukan diluar pernikahan kudus atau dengan pasangan yang tidak sah adalah perbuatan yang menjijikkan bagi Tuhan dan menjadi momok yang menggelisahkan bagi orang itu sendiri.

\section{Dimensi Seks Menurut Alkitab}

Ada beberapa dimensi seks menurut Alkitab, yaitu:

\section{Dimensi Rekreasi}

Hubungan seksual yang memiliki empat fase (desire, excitement, orgasm, resolution) memberikan kepuasan bagi suami istri yang melakukannya. Dalam perspektif seksology, neurottransmitter jelas memiliki peranan dominan untuk dimensi rekreasi. Saat seseorang mengalami orgasme, tubuhnya akan mengalami berbagai macam perubahan fisiologi yang kompleks. Setidaknya ada dua neuro-endocrine yang dihasilkan oleh tubuh saat terjadi orgasme, yaitu endorphine dan serotonine. Kedua zat ini menyebabkan tubuh menjadi amat rileks baik fisik maupun psikis. Kondisi rileks yang dimaksud sebagai dimensi rekreasi dari seks. Jadi, secara singkat dapat dikatakan suami istri yang melakukan hubungan seksual dan mengalami orgasme menghasilkan neuro-endocrine yang akan menyebakan rileks.

\section{Dimensi Prokreasi}

Sejak awal Allah telah menetapkan manusia sebagai ciptaan dengan kapasitas untuk bereproduksi (Kejadian 1:28; 4:1). Untuk tujuan ini Allah telah melengkapi manusia dengan organ-organ reproduksi yang memungkinkan mereka untuk bereproduksi. Di dalam tubuh seorang pria, triliunan sperma diproduksi sepanjang hidupnya, itu sebabnya hampir setip saat seorang pria dewasa yang sehat bisa mengeluarkan sekira 400 juta sel sperma dalam satu kali ejakulasi. Sementara itu seorang wanita dibekali dengan 450.000 bakal sel telur yang akan mengalami kematangan rata-rata satu sel telur setiap bulannya. Dimensi prokreasi ini sering disebut mandat budaya. Tuhan memberikan perintah kepada manusia untuk berkembang biak memenuhi seluruh bumi (Kejadian 1:28).

\section{Dimensi Relasi}

Kejadian 4:1 "Kemudian manusia itu bersetubuh dengan Hawa, istrinya, dan mengandunglah perempuan itu,.....”. Kata bersetubuh dalam Alkitab bahasa 
Indonesia, ternyata dalan KJV digunakan kata knew (to know) berarti: mengenal, mengerti, mengetahui. Kata knew yang diterjemahkan Adam bersetubuh dengan Hawa menyatakan bahwa hubungan seksual adalah suatu proses pengenalan, suatu proses membangun relasi, relasi yang sangat intim, itu sebabnya seks memiliki dimensi relasi. Seks menciptakan relasi yang sangat harmonis diantara seorang laki-laki dan perempuan yang telah dipersatukan Tuhan. Relasi yang rukun akan menghasilkan suasa yang tenang, aman dan sejahtera.

\section{Dimensi Refleksi}

Allah menciptakan manusia menurut gambar dan rupa-Nya, laki-laki dan perempuan diciptakan-Nya mereka (Kejadian 1:27). Allah memiliki tujuan menciptakan manusia dengan mengaruniakan gairah seksual. Hubungan seksual di antara laki-laki dan perempuan di dalam pernikahan merupakan gambaran ikatan perjanjian dan kesenangan-kesenangan dalam relasi Allah dengan umat-Nya. Bahasa dan gambaran seksualitas adalah perumpamaan yang begitu jelas dan paling kuat Alkitab gunakan untuk menggambarkan relasi antara Allah dan gereja-Nya.

Rasul Paulus menuliskan dalam Efesus 5:31-32, "Sebab itu laki-laki akan meninggalkan ayahnya dan ibunya dan bersatu dengan istrinya, sehingga keduanya itu menjadi satu daging. Rahasia ini besar, tetapi yang aku maksudkan ialah hubungan Kristus dan jemaat". Hubungan seksual adalah gambaran hubungan Kristus dan jemaat yang penuh keintiman. Istilah satu daging adalah metafora relasi yang unik antara Kristus dan gereja-Nya (Yohanes 17:21-23).

\section{Kontribusinya Bagi Pengajaran Gereja Masa Kini}

Era kemajuan teknologi saat ini, memperlihatkan bahwa dosa seksual semakin marak dilakukan oleh manusia tidak terkecuali orang Kristen. Media elektronik dan media cetak terus memberitakan meningkatnya angka perselingkuhan, pelecehan seksual, seks di luar nikah dan cyber sex terjadi dimana-mana. Gereja harus menanggapi peristiwa tersebut sebagai tantangan spiritual dan moral manusia, sehingga dapat menetapkan langkah-langkah untuk menanggulanginya. Ada beberapa upaya penanganan dan pencegahan dosa seks yang dapat dilakukan oleh gereja atau para hamba Tuhan sebagai berikut:

\section{Pendidikan Seks Yang Alkitabiah}

Pendidikan seks adalah suatu pengetahuan, informasi dan nilai-nilai yang diajarkan mengenai segala sesuatu yang berhubungan dengan jenis kelamin. Pembahasan yang dapat dipaparkan misalnya: Pertumbuhan jenis kelamin, fungsi alat kelamin, sistim reproduksi, perubahan hormon dan hubungan seksual. Pendidikan seks harus disampaikan menurut konsep Alkitab sebagai dasar iman kekristenan. Alkitab adalah dasar dari pengajarang tentang seks sebab orang Kristen meyakini ineransi dan infabilitas Alkitab. Ineransi Alkitab berarti bahwa Alkitab tidak ada kekeliruan atau kesalahannya, sedangkan infabilitas Alkitab berarti bahwa Alkitab bebas dari kecenderungan melakukan kesalahan. Karena Alkitab diispirasikan oleh Allah, maka Alkitab tidak dapat salah atau tidak memiliki kekeliruan. Sehingga pendidikan seks yang akurat dan benar ialah konsep seks yang dibangun dari ayat-ayat suci Alkitab seperti yang telah diuraikan pada bagian sebelumnya. 
Tulisan Rasul Paulus dalam 2 Timotius 3:16: "Segala tulisan yang diilhamkan Allah memang bermanfaat untuk mengajar, untuk menyatakan kesalahan, untuk memperbaiki kelakuan dan untuk mendidik orang dalam kebenaran". Rasul Paulus menjelaskan bahwa Alkitab adalah sumber pengajaran dan dasar kehidupan orang percaya. Sebab Alkitab berbicara tentang kehidupan manusia secara komprehensif termasuk soal seks, maka isi Alkitab harus diajarkan secara utuh dan gamblang. Gereja tidak boleh malu dan tertutup berbicara tentang seks, tetapi para hamba Tuhan, majelis gereja, para aktifis, para orang tua harus menyampaikannya agar semua anggota gereja mengalami pertobatan dan pemulihan dari dosa seks serta mampu memelihara kekudusan seksual di hadapan Tuhan.

\section{Program Bersifat Prefentif}

Gereja harus mengambil posisi terdepan untuk penanganan dan pencegahan dosa seksual baik di dalam internal jemaat maupun di lingkungan masyarakat pada umumnya. Gereja yang dihadirkan Tuhan sebagai garam dan terang di dalam dunia harus membawa perubahan pada semua aspek kehidupan manusia khususnya spiritualitas. Salah satu cara agar tujuan tersebut dapat terwujud apabila gereja memiliki ide atau gagasan yang kreatif dan inofatif untuk menyiapkan program yang berdampak pada perubahan hidup dan peningkatan kualitas iman jemaat kepada Tuhan. Kaitannya dengan masalah seks para hamba Tuhan dapat menggunakan momentum khotbah untuk mengajarkannya kepada para jemaat. Kemudian metode lain ialah melalui diskusi kelompok kecil, pemuridan, konseling pranikah, katekisasi, seminar dan penerbitan literatur yang membahas materi tentang seks.

\section{Pelayanan Pastoral Konseling}

Sebagaimana telah dipaparkan pada bagian sebelumnya bahwa seseorang yang melakukan dosa seksual akan berdampak pada kehidupan rohani, psikologi, fisik dan sosial. Salah satu cara penyelesaiannya ialah gereja melaksanakan pelayanan pastoral konseling. Istilah konseling berasal dari bahasa Latin, yaitu: "concilium" yang berarti "dengan" atau "bersama" yang dirangkai dengan "menerima" atau "memahami". Maka, pastoral konseling ialah interaksi yang terjadi antara dua orang individu, masingmasing disebut konselor dan klien.

Tujuan utama dalam konseling Kristen adalah menolong seseorang menyelesaikan persoalan demi memenuhi tujuan mula-mula Allah dalam hidupnya, yakni menjadi serupa dengan Kristus bagi kemuliaan Bapa di Sorga (Rm. 8:29, II Kor.3:18, Yes. 43:7). Selanjutnya Tulus Tu'u merumuskan ada 10 (sepuluh) tujuan pastoral konseling, yakni: 1. Mencari yang hilang; 2. Menolong yang membutuhkan uluran tangan; 3. Mendampingi dan membimbing; 4. Berusaha menemukan solusi; 5. Memulihkan kondisi yang rapuh; 6. Perubahan sikap dan perilaku; 7. Menyelesaikan dosa melalui Kristus; 8. Pertumbuhan iman; 9. Terlibat persekutuan jemaat; 10. Mampu menghadapi perseolan selanjutnya. Oleh karena itu, pentingya pelayanan pastoral konseling kepada jemaat yang memiliki pergumulan terhadap dosa seksual, agar dapat mengalami pemulihan secara utuh serta mengambil keputusan untuk hidup baru di dalam Kristus Yesus. 


\section{Kesimpulan}

Seks merupakan ciptaan Tuhan yang teramat baik bagi manusia. Allah mengaruniakan seks agar manusia memiliki keintiman, kesatuan dan kenikmatan dengan pasangan lawan jenisnya. Seks tidak boleh dimengerti secara keliru. Seks bukan sesuatu yang kotor atau alat untuk pemuasan hasrat manusia sesaat, tetapi seks adalah suci di hadapan Tuhan. Alkitab menyaksikan bahwa perilaku seks yang diizinkan Allah ialah hubungan seksual yang dilakukan oleh pasangan laki-laki dan perempuan yang telah diberkati dalam pernikahan kudus. Sebaliknya semua perilaku seks di luar pernikahan yang diberkati Tuhan adalah dosa. Oleh karena itu, gereja memiliki peran penting untuk memberikan pengajaran seks kepada setiap anggota jemaat berdasarkan Firman Allah yang suci, agar mampu menjaga kekudusan seksual baik sebelum menikah maupun setelah masuk dalam pernikahan. 


\section{Kepustakaan}

\section{Buku}

Abineno, C. L. Ch., 1980 Seksualitas Dan Pendidikan Seksual, Jakarta: BPK Gunung Mulia

Enns, Paul., 2018 The Moody Handbook Of Theology I, Malang: Literatur SAAT

Erman Amti, Prayitno., 2008 Dasar-dasar Bimbingan Dan Konseling, Jakarta: Rineka Cipta Green, P Jay., 1991 The Interlinier Hebrew-Aramic Old Testament, Massachusetts: Hedrickson Publisers

Hutapea, Ronal., 2014

Kruyt, S., 1976 Pendidikan Seksuil, Jakarta: BPK Gunung Mulia

Laarser, Mark., 2005 Membicarakan Seks Dengan Anak Anda, Bandung: Kerygma Publisers

Lauer, Robert H., 1993

Perspektif Tentang Perubahan Sosial, Jakarta: Rineka Cipta Mayo, Ann Mary., 1986

Pendidikan Seks Dari Orang Tua Kepada Anak, Bandung: Yayasan Kalam Hidup

Miles, J. Herbert., 1996 Sebelum Menikah Pahamilah Dulu Seks, Jakarta: BPK Gunung Mulia

Moeliono, A., $1988 \quad$ Kamus Besar Bahasa Indonesia, Jakarta: Balai Pustaka Owens, Joseph John., 1918 Analytical Key To The Old Testament, Michigan: Baker Book House Piper, John., 2008 Seks Dan Supremasi Kristus, Surabaya: Momentum

Roemokoij, Danny., 1989

AIDS Nuklir Sorga, Batu

Soekahar, $\mathrm{H}$, $1987 \quad$ Homoseksual, Yogyakarta: Andi

Strong, James., 1960 The Exhaustive Concordance of The Bible, Massachusetts: Hedrickson Publisers, tth

Thiessen, C. Hanry., 2008

Teologi Sistimatika, Malang: Gandum Mas

Tulus, Tu'u., 2007 Dasar-dasar Konseling Pastoral, Yogyakarta: ANDI Wiarto, Giri., 2015

Psikologi Perkembangan Manusia, Yogyakarta: Psikosain 
Wijarko, Jarot., 2012 Cinta Sex Pacaran, Jakarta: Suara Pemulihan

White, John., 2003 Dosa, Seks, Dan Kita (Jakarta: PT Gloria Usaha Mulia Wijaya, Andik., 2014 Sexual Holiness Vol. 1, Surabaya: Kenza Publising House 2014 Sexual Holiness Vol. 3, Surabaya: Kenza Publising House 2014 Sexual Holiness Vol. 4, Surabaya: Kenza Publising House $2014 \quad$ Sexual Holiness Vol. 5, Surabaya: Kenza Publising House

\section{Internet}

- $\quad$ https://www.evitworld.blogspot.com, On Line: Selasa, 12 Maret 2018

- $\quad$ https://www.eprints.ums.ac.id, On Line: Rabu, 14 Maret 2018

- https://www.rehobot.org/beranda_renungan/hal-perzinaan, On Line: Rabu, 11 September 2019

- https://id.wikipedia.org/wiki/Pedofilia, On Line: Minggu, 15 September 2019 